\title{
GEORGE FOX
}

AND EARLY

\section{QUAKER \\ C ULT URE}



chesterhive.com at $04 / 26$ HWIARY HIN D S 
George Fox and early Quaker culture

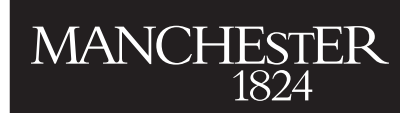

Manchester University Press 
Hilary Hinds - 9781847794598 Downloaded from manchesterhive.com at 04/26/2023 11:11: ๑6AM via free access 


\title{
George Fox and early Quaker culture
}

\author{
Hilary Hinds
}

\section{Manchester University Press}

Manchester and New York

distributed in the United States exclusively by Palgrave Macmillan 
Copyright (C) Hilary Hinds 2011

The right of Hilary Hinds to be identified as the author of this work has been asserted by her in accordance with the Copyright, Designs and Patents Act 1988.

Published by Manchester University Press

Oxford Road, Manchester M13 9NR, UK

and Room 400, 175 Fifth Avenue, New York, NY 10010, USA

www.manchesteruniversitypress.co.uk

Distributed in the United States exclusively by

Palgrave Macmillan, 175 Fifth Avenue, New York,

NY 10010, USA

Distributed in Canada exclusively by

UBC Press, University of British Columbia, 2029 West Mall,

Vancouver, BC, Canada V6T 1Z2

British Library Cataloguing-in-Publication Data

A catalogue record for this book is available from the British Library

Library of Congress Cataloging-in-Publication Data applied for

ISBN 9780719081576 hardback

First published 2011

The publisher has no responsibility for the persistence or accuracy of URLs for any external or third-party internet websites referred to in this book, and does not guarantee that any content on such websites is, or will remain, accurate or appropriate.

Typeset in Bembo

by Servis Filmsetting Ltd, Stockport, Cheshire

Printed in Great Britain

by TJ International Ltd, Padstow 